\title{
Evaluation of the internal stability of well-graded silty sand through the long-term seepage test
}

\author{
Hee-Jun Lee ${ }^{*}$, In-Hyun Kim and Choong-Ki Chung
}

*Correspondence:
hjlee99@snu.ac.kr
Department of Civil
and Environmental
Engineering, Seoul National
University, 08826 Seoul,
South Korea

South Korea

\begin{abstract}
Suffusion is the phenomenon responsible for internal erosion, and is the process by which finer soil particles are moved through the constrictions between the larger soil particles by seepage forces. Generally, gap-graded soil is known to be susceptible to suffusion. Meanwhile, suffusion of well-graded silty sand and the resulting soil behavior are not well understood. Moreover, the previous researches on laboratory suffusion tests focused on the study of the critical hydraulic gradient, which triggers the internal instability of the soils within a short period of time. Therefore, in this study, long-term suffusion tests were conducted on well-graded silty sand under a hydraulic gradient lower than the critical value. As a result, abrupt increases in permeability and amount of soil discharged were observed due to the progressive migration of the soil particles, resulting in suffusion even at a relatively low hydraulic gradient.
\end{abstract}

Keywords: Internal erosion, Internal instability, Suffusion, Well-graded silty sand

\section{Introduction}

Hydraulic earth structures, like levees and dams, can undergo various kinds of damage. Among these, internal erosion, overtopping, and slope instability are the major possible failure modes. Foster et al. [6] reported that 57 of the 126 cases of dam failure abroad were caused by internal erosion, representing $45 \%$ of the total number of failures. The other major failure modes (overtopping and slope instability) make up about 44 and $4 \%$, respectively. Hence, internal erosion can be regarded as one of the main cause of damage in hydraulic earth structures.

Suffusion is the phenomenon responsible for internal erosion, and is the process by which finer soil particles are moved through the constrictions between the larger soil particles by seepage forces Wan and Fell [16]. Once the fine particles are removed, the permeability of the soil will increase locally. This can induce a reduction of shear strength and a mutation of hydraulic condition [3]. Furthermore, there are various types of dam breaches that can be induced by suffusion, such as increase in seepage, leading to the initiation of backward erosion piping; formation of voids in the foundation, leading 
to the settlement of the crest and overtopping; and increase in pore pressure and loss of strength in the embankment or foundation, leading to a downstream slide [4, 7].

Based on the survey conducted by the National Disaster Management Research Institute [13], in South Korea, 17,611 of the 17,702 hydraulic earth structures are earth-fill dams. Most of the fill dams of South Korea are made up of well-graded silty sand decomposed from granite and gneiss. Generally, gap-graded soil is known to be susceptible to suffusion. Several dams with well-graded soils in South Korea, however, have suffered from internal erosion.

The occurrence of suffusion in hydraulic earth structures is difficult to predict, because it readily develops into other failure mechanism types. Therefore, the vulnerability of soils to suffusion is often assessed based on the laboratory seepage tests. In evaluating the internal stability through the seepage tests, there are two important conditions governing the onset of suffusion: the geometric and hydraulic conditions. According to the previous studies on the geometric conditions, criteria for internal instability have been suggested based on the grain size distribution, because the large constriction size formed by the coarse particles allows fine particles to be washed away (Istomina [8]; Kezdi [10]; Kenney and Lau [9]; Burenkova [2]; Wan and Fell [16]). In terms of the hydraulic condition, the previous researches focused on the hydraulic gradient, which triggers suffusion (Skempton and Brogan [14]; Bendahmane et al. [1]; Chang and Zhang [4]; Moffat and Fannin [12]. Chang and Zhang [3] defined the critical hydraulic gradient as a hydraulic gradient that the fine particles start to erode by increasing the hydraulic gradient within $8 \mathrm{~h}$.

Most seepage tests, however, are conducted on gap-graded soils, because these show clear manifestation of suffusion. Additionally, in evaluating the critical hydraulic gradient, tests are carried out for only a short period of time. Therefore, the objective of this research is assessing the vulnerability of well-graded silty sand to suffusion at a relatively low hydraulic gradient through the long-term seepage test.

\section{Experiment program}

The specimens that were used in the seepage tests were gap-graded silty sand, artificially constituted; and Gwanak soil, well-graded silty sand which has the representative grain size distribution of the fill dams in South Korea. Gap-graded silty sand was mixed with sand $(2 \sim 4.75 \mathrm{~mm})$ and silt $(<0.15 \mathrm{~mm})$, collected from the Gwanak soil, accounting for 85 and $15 \%$ of the specimen, respectively. The grain size distribution and properties of gap-graded silty sand and Gwanak soil are shown in Table 1 and Fig. 1.

Table 1 Properties of gap-graded silty sand and Gwanak soil

\begin{tabular}{lll}
\hline Material & Gap-graded silty sand & Gwanak soil \\
\hline \% passing through sieve no. 200 & 8.2 & 40 \\
Specific gravity $\left(G_{s}\right)$ & 2.65 & 2.59 \\
Maximum dry unit weight $(\mathrm{g} / \mathrm{cm} 3)$ & 1.76 & 1.86 \\
Uniformity coefficient $\left(C_{u}\right)$ & 28 & 112 \\
Permeability coefficient $(\mathrm{cm} / \mathrm{s})$ & $0.9 \times 10^{-3}$ & $0.2 \times 10^{-3}$ \\
& $(\mathrm{e}=0.57)$ & $(\mathrm{e}=0.74)$ \\
\hline
\end{tabular}




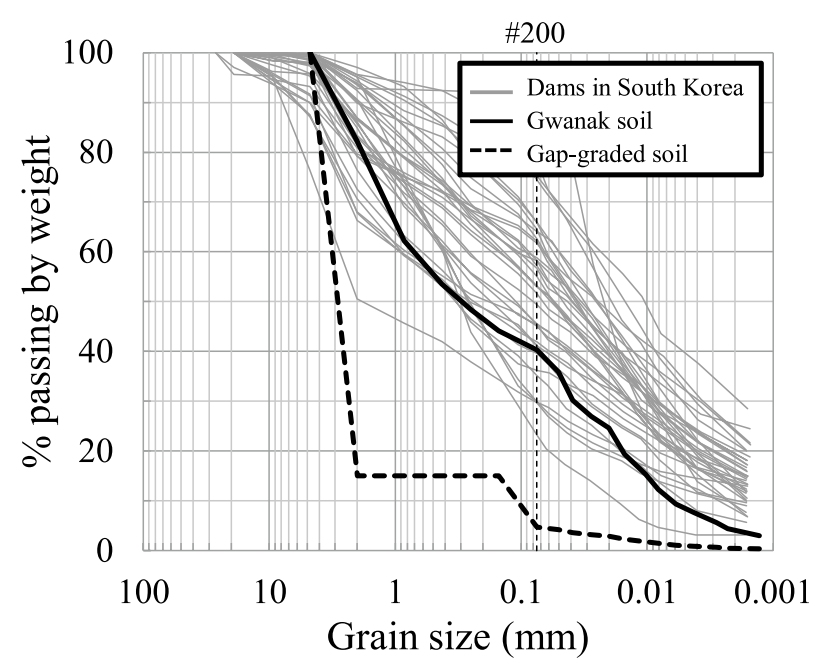

Fig. 1 Grain size distributions of gap-graded silty sand and Gwanak soil

Suffusion tests are carried out based on the procedure of the U.S. Army Corps of Engineers (USACE 1953), which evaluated the internal stability of the filter materials. The experimental apparatus that was used in the tests have been developed and modified by several researchers (Kenney and Lau [9]; Wan and Fell [16]). Experimental apparatus of this research is consisted of a water tank, an outer cell, an inner cell, and a collector. The water tank can maintain the water level of the inlet constant, and the outlet can keep the head of the outer cell at a constant level. In the inner cell, submerged inside the outer cell, there is a cylindrical specimen (diameter: $10 \mathrm{~cm}$; height: $10 \mathrm{~cm}$ ) installed over a pore plate. The plate has 80 holes with a $4 \mathrm{~mm}$ diameter in accordance with the filter criteria (the filter material size $15 \%$ finer by weight should be 4 times smaller than the $85 \%$ finer base material size). Water flows downward through the specimen, and the discharged soil with water is accumulated in the collector. During the experiment, the amount of water can be measured directly from the outlet tube, and the amount of discharged soil can be obtained by drying the soil in the collector (Fig. 2).

Gap-graded silty sand and Gwanak soil were compacted to reach 80 and $50 \%$ relative densities $\left(D_{r}\right)$ to show clear manifestation of suffusion. Short-term tests were conducted to determine the critical hydraulic gradient, which initiates internal instability by increasing the hydraulic gradient stepwise. For each hydraulic gradient, tests were maintained for $1 \mathrm{~h}$. Long-term tests were conducted at a hydraulic gradient of 5 for the gapgraded soil and 17 for the Gwanak soil. Long-term tests were conducted to determine if the soil could reach a state of internal instability under a hydraulic gradient relatively lower than the critical value (Table 2).

\section{Test results}

\section{Short-term test}

In the case of the gap-graded silty sand, progressive increases in the amount of soil discharged and coefficient of permeability $(k)$ were recorded at the early stage of the tests 


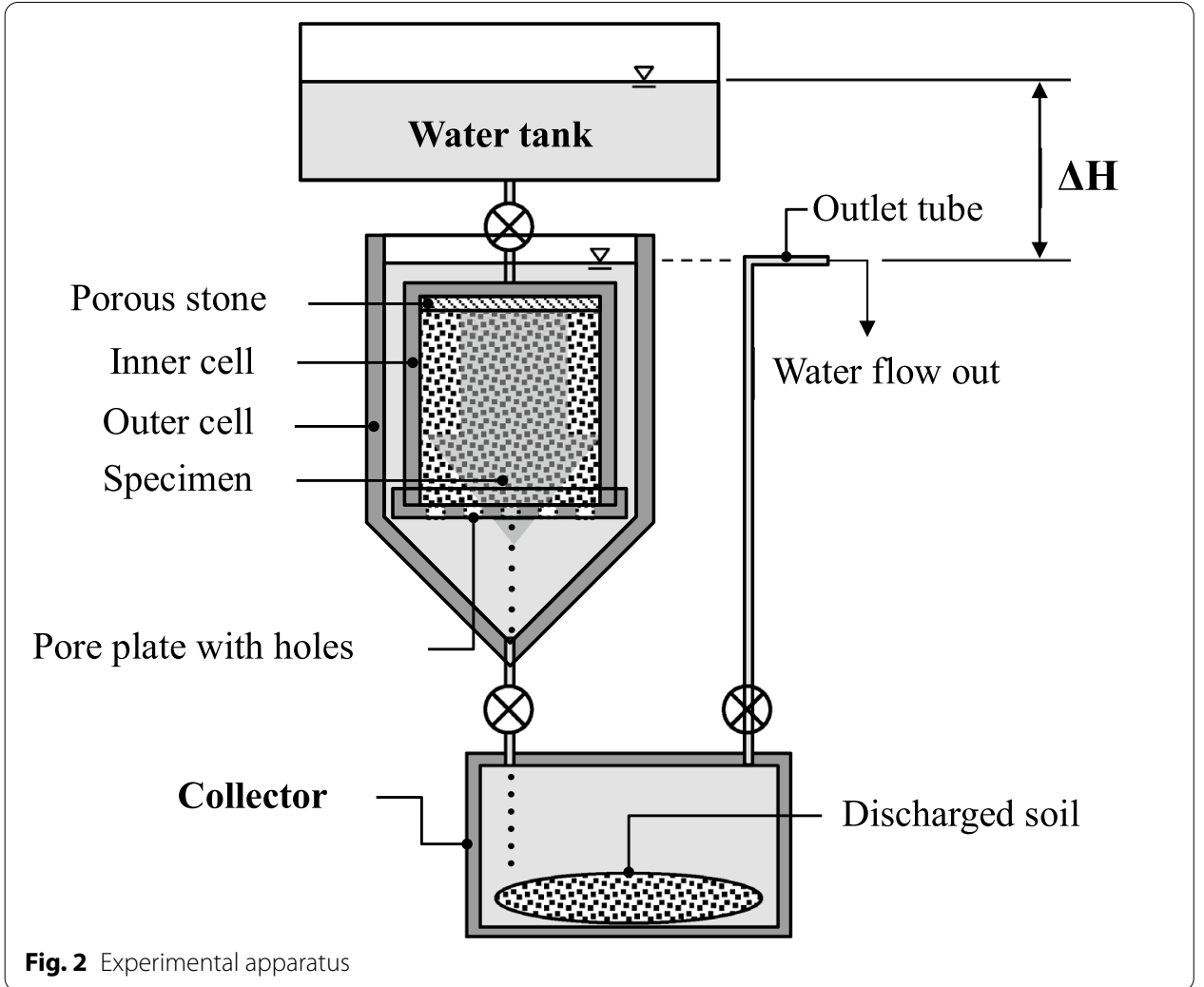

Table 2 Summary of the experiment program

\begin{tabular}{llll}
\hline Test & Specimen & $\boldsymbol{D}_{\boldsymbol{r}}(\%)$ & Applied hydraulic gradient \\
\hline Short-term test & Gap-graded silty sand & 80 & $0.5,1,2,3,4,5,6,7,8,9,10,12$ \\
& Gwanak soil & 50 & $2,5,10,15,20,25,30,35,40$ \\
Long-term test & Gap-graded silty sand & 80 & 5 \\
& Gwanak soil & 50 & 17 \\
\hline
\end{tabular}

(hydraulic gradient, $i=0.5$ ). Later, at the hydraulic gradient of 10 , they increased significantly. As a result, the accumulative discharged soil reached $4.1 \%$ of the total mass of the specimen at the hydraulic gradient of 12 (Fig. 3a). Upon the completion of the test, $k$ reached almost 3 times the initial coefficient of permeability $\left(k_{0}\right)$. Meanwhile, no noticeable settlement occurred during the test, and the estimated void ratio $(e)$ increased from 0.57 to 0.62 due to the selectively discharged soil. Based on the grain size distribution analysis, $97 \%$ of the discharged soil turned out to be the fine particles passing sieve no. 100, resulting in the shifting of the grain size distribution curve of the specimen (Fig. 3b). As the abrupt increases in the amount of discharged soil and $k$ at the hydraulic gradient of 10 can be regarded as a critical hydraulic gradient state, a long-term test was conducted under the hydraulic gradient $(i=5)$, half the critical value obtained from this test.

When the test was conducted on Gwanak soil under the hydraulic gradient below 30, a continuous reduction of $k$ was observed despite the release of the soil particles (1.2\%). 


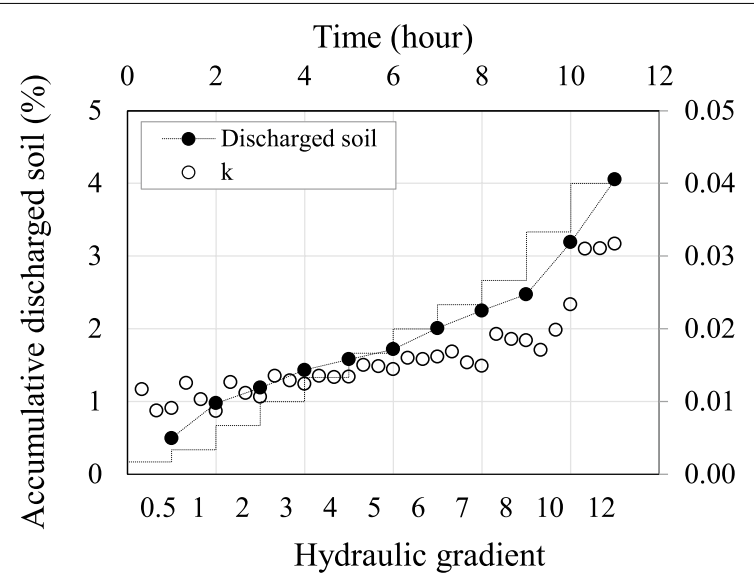

(a)

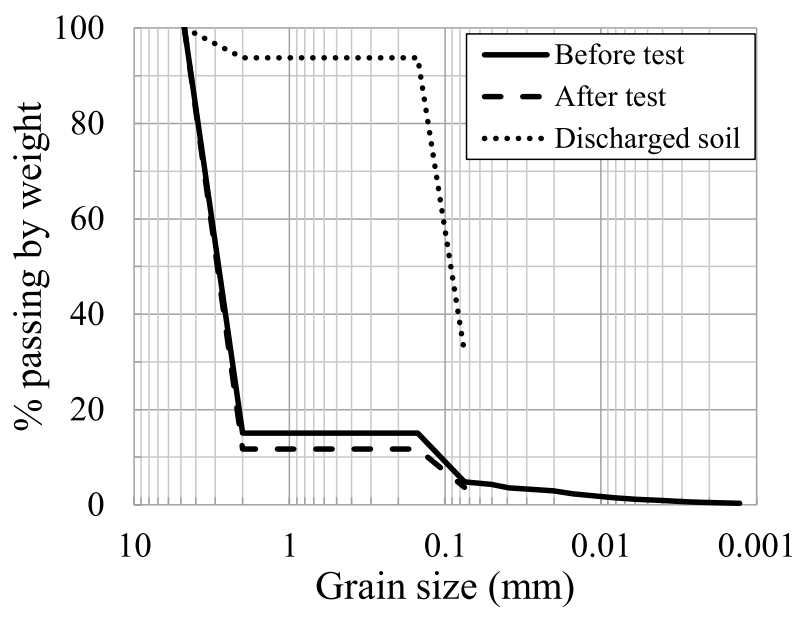

(b)

Fig. 3 Short-term test results of gap-graded silty sand: a accumulative discharged soil and $k$; and $\mathbf{b}$ grain size distribution after the test

However, when the test was proceeded to reach the hydraulic gradient of $35, k$ increased sharply, reaching 1.5 times $k_{0}$, together with the significant amount of soil discharged. Accordingly, at the hydraulic gradient of 40 , the accumulative discharged soil reached $5.1 \%$, and the estimated $k$ reached approximately 1.2 times $k_{0}$ (Fig. $4 \mathrm{a}$ ). The reduction of $k$ below the hydraulic gradient of 30 was due to the different degree of effective stress and the probability of clogging that the fine fraction was subjected to. The influence of stress and clogging will be discussed in detail later. After the experiment, a $0.4 \mathrm{~mm}$ settlement was developed, but $e$ nonetheless increased from 0.74 to 0.83 . The grain size distribution of the discharged soil showed that the percentage of fine particles passing sieve no. 100 was $73 \%$ ( $44 \%$ in the original specimen), producing a grain size distribution curve that showed a reduction in the fine fraction of the original specimen (Fig. 4b). Taking account of the significant changes in $k$ at the hydraulic gradient of 35 as an indication of a critical 


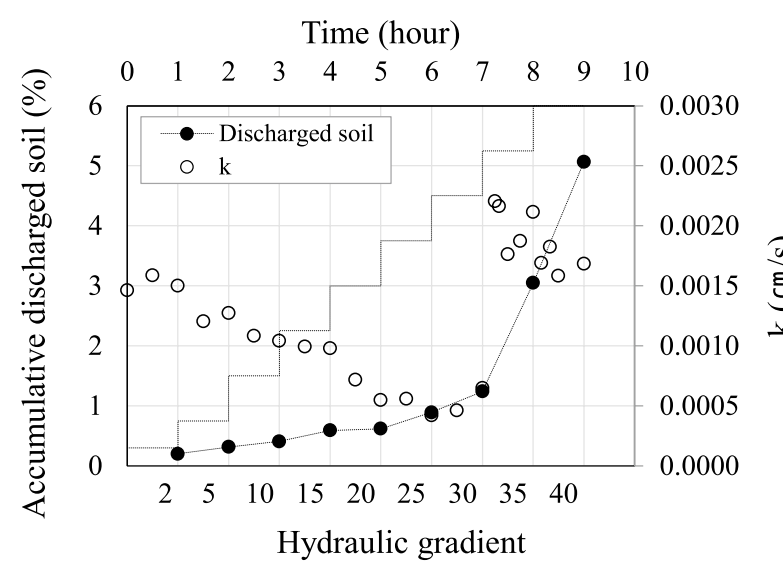

(a)

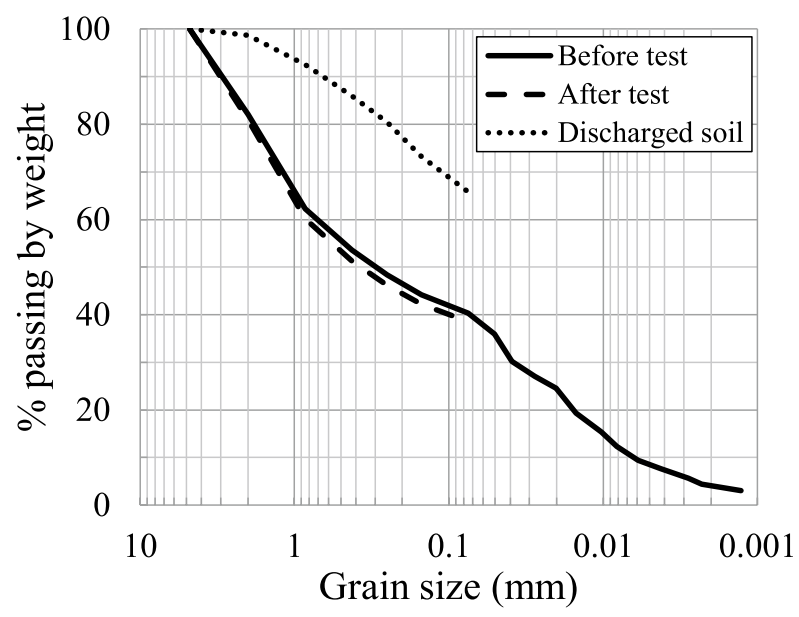

(b)

Fig. 4 Short-term test result of Gwanak soil: a accumulative discharged soil and $k$; and $\mathbf{b}$ grain size distribution after the test

hydraulic gradient state, the hydraulic gradient of 17 was applied for the long-term tests, determined in the same manner as with the gap-graded specimen.

\section{Long-term test}

When the test of gap-graded silty sand was continued for $11 \mathrm{~h}$ under the hydraulic gradient of 5 (the full time that elapsed for the short-term test), accumulative discharged soil reached $12.4 \%$, and at the end of the test the total, discharged soil reached $14 \%$. During the first hour of the experiment, a significant amount of soil was discharged, and then the erosion rate of the soil gradually decreased (Fig. 5a). Accordingly, a rapid increase in $k$ was observed, and a level twice $k_{0}$ was maintained. After the test, a $0.4 \mathrm{~mm}$ settlement was observed, and $e$ significantly increased from 0.54 to 0.78 . Based on the grain size distribution analysis, $95 \%$ of the discharged soil turned out to be the fine particles passing sieve no. 100 (Fig. 5b). It should be noted that in the case of the long-term test, the 


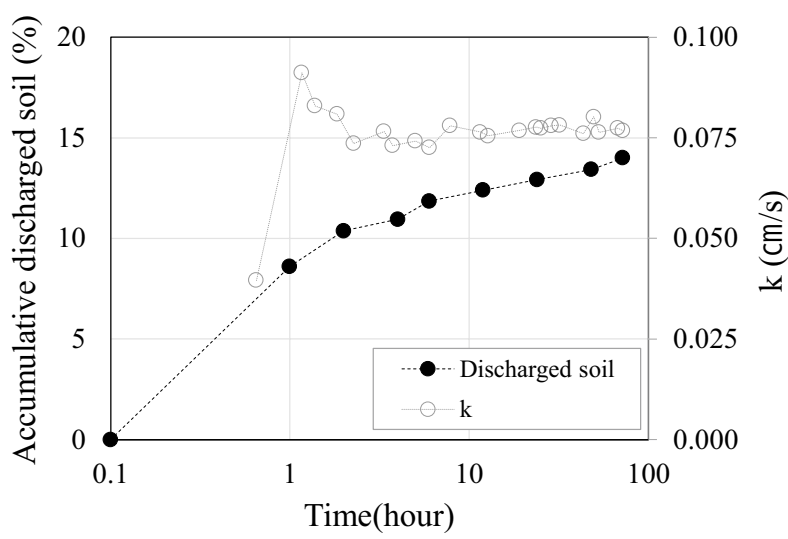

(a)

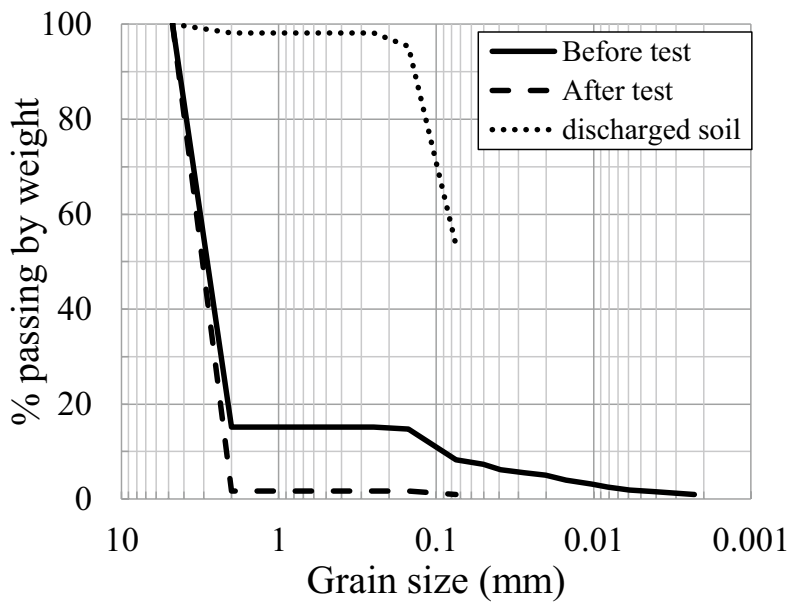

(b)

Fig. 5 Long-term test results of gap-graded silty sand: a accumulative discharged soil and $k$; and $\mathbf{b}$ grain size distribution after the test

amount of soil discharged within $11 \mathrm{~h}(12.4 \%)$ was greater than that in the short-term test (4.1\%). Such peculiarity may have resulted from the different methods of subjecting the specimen to a hydraulic gradient. During the short-term test, the soil was initially under a relatively low hydraulic gradient $(i=0.5-5)$, and the gradient was increased stepwise, stabilizing the soil structure. Therefore, compared to the long-term test result, a relatively smaller amount of soil was discharged in the short-term test.

After around $9 \mathrm{~h}$ testing of the Gwanak soil $(i=17)$, the same testing time as in the short-term test, the accumulative discharged soil that was collected was $2.7 \%$. Up to 11 days, a progressive reduction in $k$ was shown, together with the erosion rate (Fig. 6a). Later, the erosion rate started to increase slightly, inducing an abrupt increase in $k$ from around 15 days. Consequently, after experiencing a surge in the 


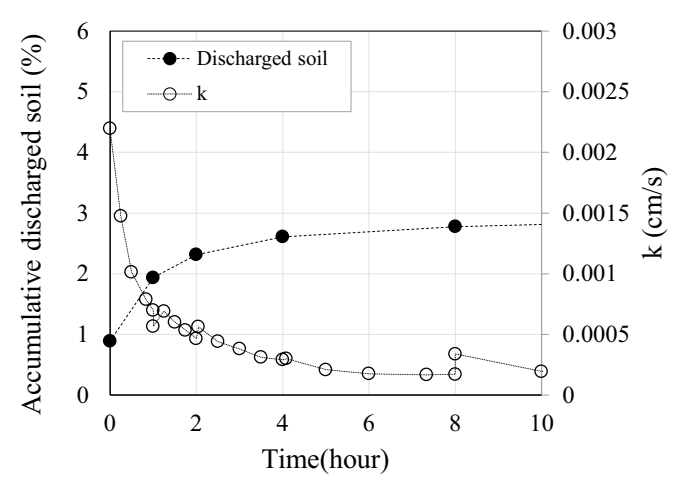

(a)

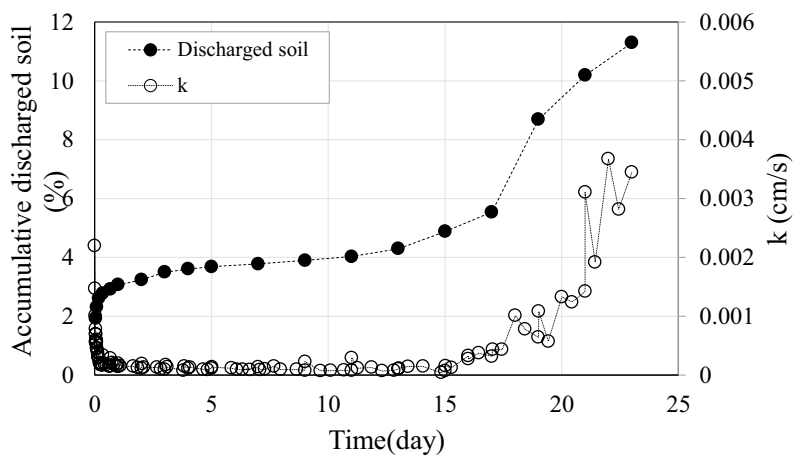

(b)

Fig. 6 Long-term test results of Gwanak soil: accumulative discharged soil and $k$ for $\mathbf{a} 10 \mathrm{~h}$ and $\mathbf{b} 23$ days

erosion rate, the accumulative discharged soil reached $11.3 \%$, and the estimated $k$ was shown to be almost 3 times $k_{0}$ (Fig. $6 \mathrm{~b}$ ).

During the test, the settlement was accompanied by the rate of soil discharged, resulting in a $7.6 \mathrm{~mm}$ subsidence. $e$ slightly decreased from 0.76 to 0.74 up to 4 days, but gradually increased with the discharge of soil, and finally reached 0.79 (Fig. 7a). The post-test grain size distribution showed that the fine particles (passing sieve no. 100 ) in the discharged soil increased, reaching $75 \%$ (44\% in the original specimen; Fig. 7b)). According to the gradation analysis, a significant amount of coarse particles was discharged together with the fine particles, inducing a collapse of the soil structure, which resulted in the settlement of the soil specimen. On the contrary, such destructive behavior was not observed in the case of gap-graded silty sand.

\section{Discussion}

The test results of the gap-graded silty sand showed that the specimen is internally unstable within a short period of time, which can be attributed to the soil structure. When the constriction size of the coarse particles is larger than the size of the fine particles, the fine particles are under a small effective stress and can be easily moved by the seepage force. Therefore, the washing out of the fine particles within the soil increases the $\mathrm{d} 10$ (diameter of the $10 \%$ mass passing), $e$, and $k$ of the soil, rapidly leading to a state of internal instability. 


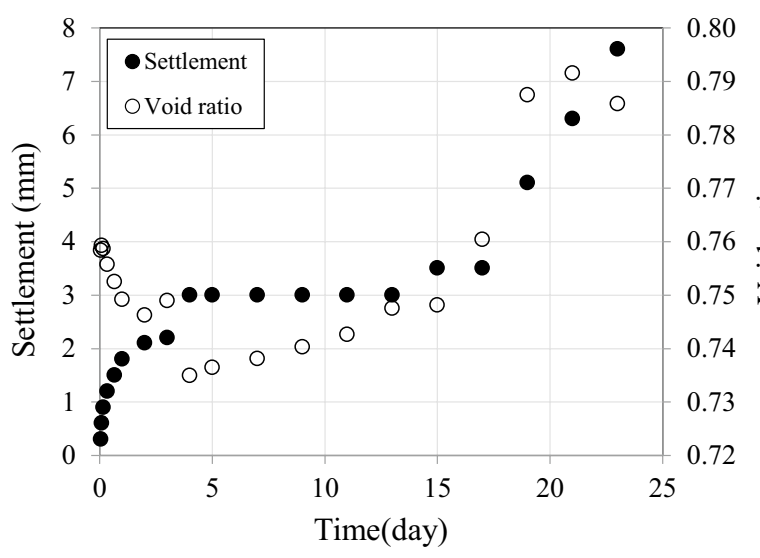

(a)

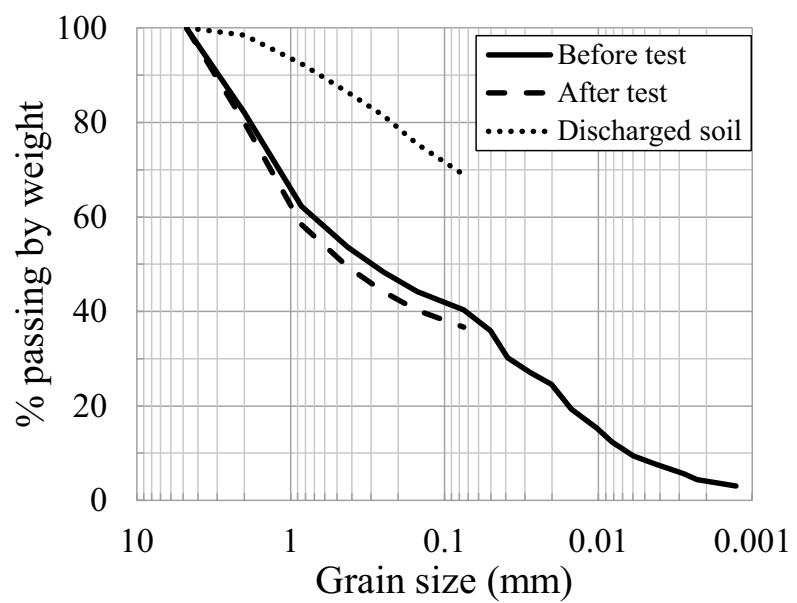

(b)

Fig. 7 Long-term test results of Gwanak soil: a settlement and e; and $\mathbf{b}$ grain size distribution after the test

Based on the long-term test results of Gwanak soil, however, the change in $k$ shows different aspects before and after 15 days. Therefore, it is necessary to take account not only of the short-term seepage test results but also of the long-term behavior of the soil, to carry out thorough evaluation of the internal stability of well-graded soils. The different aspects of the change in permeability can be explained with fine particle migration and clogging.

The constriction size and permeability of the well-graded silty sand are smaller than those of the gap-graded silty sand, thus exhibiting a high probability of clogging (Fig. 8). Once the fine particles are washed away, $\mathrm{d} 10$ and $e$ will increase. Therefore, the permeability is also expected to be raised. On the contrary, once the fine particles are clogged, the $\mathrm{d} 10, e$, and permeability will be decreased. If the fine particles are clogged in the middle part of the specimen, the local permeability of such part will be reduced (Fig. 9). When the overall hydraulic gradient is constant and the fine particles are clogged in the middle part, the decrease in local permeability can result in the reduction of the total permeability, developing a greater local hydraulic gradient. In this case, the local 


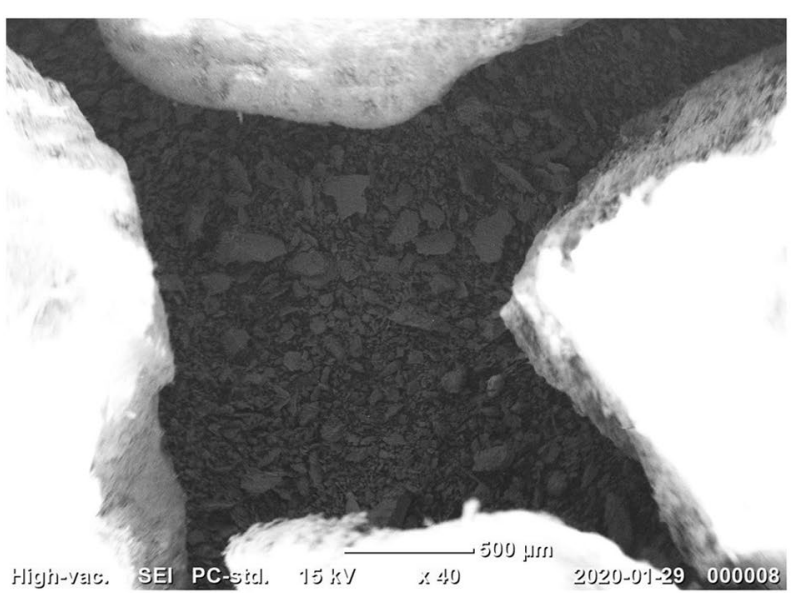

(a)

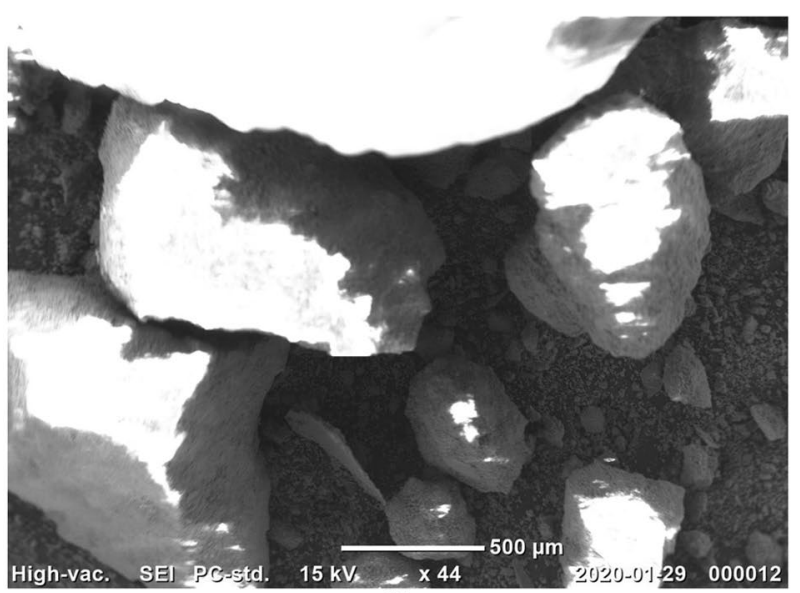

(b)

Fig. 8 SEM images: a gap-graded silty sand; and $\mathbf{b}$ Gwanak soil

hydraulic gradient may exceed the critical value obtained from the short-term test, leading to a state of internal instability of the soil.

To validate the hypothetical case mentioned above, the seepage test results obtained by Kim [11] were incorporated in this paper. Kim [11] conducted suffusion tests on wellgraded silty sand, and according to the gradation analysis of each part of the specimen (the top, transition, and bottom layers), the fine contents of the bottom layer decreased from 40 to $32 \%$ (passing sieve no. 200). Accordingly, it is assumed herein that $30 \%$ of the fine contents are migrated from the top and bottom parts of the specimen, and that the fine particles moving from the top are clogged in the middle part. In this way, 32, 47, and $32 \%$ fine contents can be achieved in the top, middle, and bottom parts, respectively. The coefficient of permeability $(k)$ of each part was calculated through the predictive method (Eq. (1); Chapuis [5]) and the overall $k$ was calculated using Darcy's Law for continuous flow in saturated media (Eq. 2), where $k=$ permeability; $\mathrm{d}_{10}=$ diameter of the $10 \%$ mass passing; $e=$ void ratio; $v=$ velocity of flow; $i=$ hydraulic gradient. 


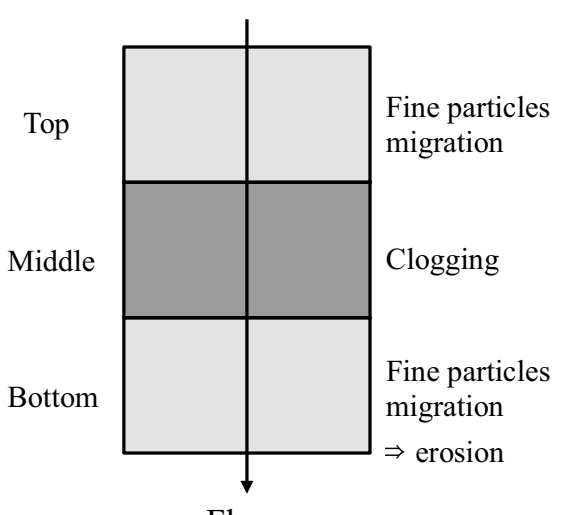

Flow

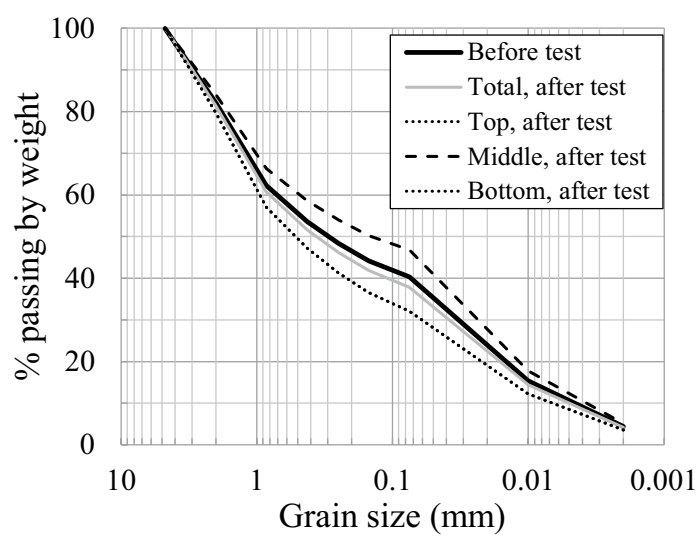

Fig. 9 Hypothetical grain size distribution based on the test results of Kim [1 1]

Table 3 Summary of analysis results

\begin{tabular}{llllll}
\hline & Initial state & \multicolumn{2}{l}{ Calculation results } & \\
\cline { 3 - 6 } & & Top & Middle & Bottom & Total \\
\hline $\begin{array}{l}\text { \% passing through sieve } \\
\text { no. } 200\end{array}$ & 40 & 32 & 47 & 32 & 38 \\
Weight of part & 1058 & 310 & 395 & 310 & 1015 \\
$\mathrm{e}$ & 0.73 & 0.97 & 0.54 & 0.97 & 0.81 \\
$\mathrm{~d}_{10}$ & 0.0065 & 0.0080 & 0.0052 & 0.0080 & 0.0070 \\
$k\left(10^{-4} \mathrm{~cm} / \mathrm{s}\right)$ & 0.96 & 2.74 & 0.31 & 2.74 & 0.76 \\
Hydraulic gradient & 17 & 4.7 & 41.5 & 4.7 & 17 \\
\hline
\end{tabular}

$$
\begin{aligned}
& k(\mathrm{~cm} / \mathrm{s})=4.236\left(\frac{d_{10}^{2} e^{3}}{1+e}\right)^{0.925} \\
& v=k i
\end{aligned}
$$

As shown in the calculation results (Table 3), $\mathrm{d} 10$ and $e$ increased at the top and bottom parts due to the migration of the fine particles, leading to a higher $k$. Meanwhile, in the middle part, a reduction in $k$ was shown because the clogging of the fine particles 
reduced $\mathrm{d} 10$ and $e$. Although the $\mathrm{d} 10$ and $e$ of the entire specimen increased, the total $k$ decreased. Further, the hydraulic gradient of the middle part increased to 3 times the overall hydraulic gradient (which is larger than the critical value of 35) obtained from the short-term seepage test. Therefore, it can be concluded that when the overall hydraulic gradient is constant and the fine particles are clogged locally within the soil, the decrease in local permeability can reduce the overall permeability, resulting in a greater local hydraulic gradient. Thus, if the local hydraulic gradient exceeds the critical value, the soil can undergo internal erosion.

\section{Conclusions}

In this research, suffusion tests were conducted on gap-graded and well-graded silty sands under a hydraulic gradient relatively lower than the critical value. An abrupt increase in permeability was observed at the hydraulic gradient of 10 for the short-term tests of the gap-graded silty sand. The long-term test results of the gap-graded silty sand showed that the specimen was internally unstable within a short period of time, even at the hydraulic gradient of 5 . When a short-term test of Gwanak soil was conducted under the hydraulic gradient below 30, however, the permeability slightly decreased, but it increased significantly at the hydraulic gradient of 35. During the long-term test, the permeability steadily decreased until 11 days, together with the erosion rate. After 11 days, the erosion rate was slightly raised, inducing an increase in permeability from around 15 days.

For gap-graded silty sand, the constriction size of the coarse particles is larger than the size of the fine particles. Thus, the fine particles are under a small effective stress and can be easily moved by the seepage force. As a result, the soil rapidly reaches a state of internal instability during both the short- and long-term tests, exhibiting greater permeability. On the other hand, the constriction size and permeability of well-graded silty sand are smaller than those of gap-graded silty sand; thus, the former has a higher probability of clogging. If fine particles are clogged, the local permeability can be decreased. When the overall hydraulic gradient is constant, the decrease in local permeability can result in the reduction of the total permeability and a greater local hydraulic gradient. In this case, the local hydraulic gradient may exceed the critical value, leading to internal erosion.

Most of the previous researches on suffusion focused on determining the critical hydraulic gradient. Nevertheless, the seepage test results from the long-term experiment suggest that soil can be internally unstable at a lower hydraulic gradient. In the further studies, suffusion tests will be conducted with a pore pressure transducer to verify the above assumption.

\section{Authors' contributions}

All authors read and approved the final manuscript.

Received: 12 June 2020 Accepted: 23 March 2021

Published online: 02 August 2021 
References

1. Bendahmane F, Marot D, Alexis A (2008) Experimental parametric study of suffusion and backward erosion. J Geotech Geoenviron Eng 134(1):57-67

2. Burenkova W (1993) Assessment of suffosion in non-cohesive and graded soils. In: Proceedings of filters in geotechnical and hydraulic engineering, Karlsruhe, Germany, pp 357-360

3. Chang DS, Zhang LM (2013a) Critical Hydraulic Gradients of Internal Erosion under Complex Stress States. J Geotech Geoenviron Eng 139(9):1454-1467

4. Chang DS, Zhang LM (2013b) Extended internal stability criteria for soils under seepage. Soils Foundations 53(4):569-583

5. Chapuis RP (2015) Predicting the saturated hydraulic conductivity of soils: a review. Bull Eng Geol Environ 71:401-434

6. Foster M, Fell R, Spannagle M (2000) The statistics of embankment dam failures and accidents. Can Geotech J 37:1000-1024

7. International Commission on Large Dams (ICOLD) (2017) Internal erosion of existing dams, Levees and Dikes, and their Foundations. Bulletin 164. ICOLD

8. Istomina VS (1957) Filtration Stability of Soils. Gostroizdat, Moscow (in Russian)

9. Kenney TC, Lau D (1985) Internal stability of granular filters. Can Geotech J 22(2):215-225

10. Kezdi A (1979) Soil physics. Elsevier, Amsterdam

11. Kim I (2019) Suffusion sensitivity of earth-fill dam soils in Korea through seepage tests. Master course thesis, Seoul National University

12. Moffat R, Fannin RJ (2011) Spatial and temporal progression of internal erosion in cohesionless soil. Can Geotech J 48(3):399-412

13. National Disaster Management Research Institute (2013) Report on the Sandae embankment dam failure in Gyeongju

14. Skempton AW, Brogan JM (1994) Experiments on piping in sandy gravels. Geotechnique 44(3):449-460

15. U.S. Army Corps of Engineers (USACE) (1953) Filter experiments and design criteria. Technical Memorandum. Waterways Experiment Station, Vicksburg

16. Wan CF, Fell R (2008) Assessing the potential of internal instability and suffusion in embankment dams and their foundations. J Geotech Geoenviron Eng 134(3):401-407

\section{Publisher's Note}

Springer Nature remains neutral with regard to jurisdictional claims in published maps and institutional affiliations.

\section{Submit your manuscript to a SpringerOpen ${ }^{\circ}$ journal and benefit from:}

- Convenient online submission

- Rigorous peer review

- Open access: articles freely available online

- High visibility within the field

Retaining the copyright to your article

Submit your next manuscript at $\gg$ springeropen.com 